\title{
Distribution and genetic diversity of two species of Pelasgus minnows (Leuciscidae) in southern Greece
}

\author{
Nuria Viñuela Rodríguez ${ }^{1}$, Radek Šanda ${ }^{2}$, Stamatis Zogaris ${ }^{3}$ and Jasna Vukić ${ }^{1, *}$ \\ ${ }^{1}$ Department of Ecology, Faculty of Science, Charles University, Viničná 7, Prague 2 12844, Czech Republic \\ ${ }^{2}$ Department of Zoology, National Museum, Václavské nám. 68, Prague 1 11000, Czech Republic \\ ${ }^{3}$ Hellenic Centre for Marine Research, Institute of Marine Biological Sciences and Inland Waters, Athinon-Souniou Ave., Anavissos, \\ Attica 19013, Greece
}

Received: 27 March 2020 / Accepted: 13 May 2020

\begin{abstract}
Pelasgus Kottelat \& Freyhof 2007 (Leuciscidae) is a freshwater fish genus endemic to the Southern Balkans. The distribution of most of its species is insufficiently known. Pelasgus was molecularly studied only marginally, and the genetic diversity of individual species or populations, crucial for their conservation, is completely unknown. We studied distribution and genetic diversity of Pelasgus stymphalicus (Valenciennes 1844) and Pelasgus marathonicus (Vinciguerra 1921), two widespread species from southern Greece. Our data, based on cytochrome $b$ sequences, confirmed that a number of populations whose taxonomic status had been uncertain, belong to one of these species. The distribution range of P. stymphalicus includes the Ionian mainland, from the Acheloos to Mornos rivers, and most of the Peloponnese, excluding the Evrotas and the headwaters of Alfios. The native range of Pelasgus marathonicus is the western Aegean mainland, from rivers near Athens to the Xerias river in the Pagasitikos Gulf. AMOVA showed that the genetic variance is slightly higher among than between populations. High $F_{\mathrm{ST}}$ values indicated a pronounced genetic differentiation of the populations in both species. There was a high proportion of private haplotypes and a very small number of shared haplotypes between populations in both species, which indicates uniqueness of each population and their susceptibility to human-induced changes.
\end{abstract}

\section{Keywords: cytochrome b / Pelasgus stymphalicus / Pelasgus marathonicus / Balkans / endemic species}

Résumé - Répartition et diversité génétique de deux espèces de vairons Pelasgus (Leuciscidae) dans le sud de la Grèce. Pelasgus (Kottelat \& Freyhof 2007) (Leuciscidae) est un genre de poisson d'eau douce endémique des Balkans du Sud. La distribution de la plupart de ses espèces est insuffisamment connue. Le genre Pelasgus n'a fait l'objet que d'une étude moléculaire marginale, et la diversité génétique des espèces ou des populations, cruciale pour leur conservation, est totalement inconnue. Nous avons étudié la répartition et la diversité génétique de Pelasgus stymphalicus (Valenciennes 1844) et de Pelasgus marathonicus (Vinciguerra 1921), deux espèces très répandues dans le sud de la Grèce. Nos données, basées sur les séquences du cytochrome $b$, ont confirmé qu'un certain nombre de populations dont le statut taxonomique était incertain, appartiennent à l'une de ces espèces. L'aire de répartition de P. stymphalicus comprend le continent ionien, des rivières Acheloos à Mornos, et la plus grande partie du Péloponnèse, à l'exclusion l'Evrotas et l'amont de l'Alfios. L'aire de répartition naturelle du Pelasgus marathonicus est la partie continentale occidentale de la mer Égée, depuis les rivières près d'Athènes jusqu'à la rivière Xerias dans le golfe de Pagasitikos. L'AMOVA a montré que la variance génétique est légèrement plus élevée au sein des populations qu'entre elles. Les valeurs élevées de $1 F_{\mathrm{ST}}$ indiquent une différenciation génétique prononcée des populations chez les deux espèces. Il y avait une forte proportion d'haplotypes particuliers et un très petit nombre d'haplotypes partagés entre les populations des deux espèces, ce qui indique le caractère unique de chaque population et sa sensibilité aux changements induits par l'homme.

Mots clés : cytochrome b / Pelasgus stymphalicus / Pelasgus marathonicus / les Balkans / espèces endémiques

\footnotetext{
*Corresponding author: jasna.vukicova@natur. cuni.cz
} 


\section{Introduction}

The Southern Balkans host distinctive freshwater fish assemblages, which have developed during a long and complex geological history of the area. Several biogeographic freshwater ecoregions have been recognized here, based on the distribution of fish species (Zogaris et al., 2009; Oikonomou et al., 2014). Two of these regions, the Ionian and Western Aegean (Zogaris and Economou, 2017; Vavalidis et al., 2019), lie in southern Greece. These regions substantially differ in their ichthyofaunal characteristics. While the Ionian region is known for its elevated number of species, the Western Aegean is considered species-poor (Economou et al., 2016; Zogaris and Economou, 2017). However, despite a high degree of endemism in both regions, the knowledge on genetic diversity of fish species, and often also on their exact distribution ranges and even biology, is still inadequate (Economidis, 2009; Zogaris and Economou, 2017). Recently conducted detailed genetic studies on a particular fish species have always revealed some unexpected patterns. For example, a high genetic diversity was discovered in the genus Valencia Myers 1928 (Vogiatzi et al., 2014; Freyhof et al., 2014), which led to the description of a new species from the Peloponnese and the southwestern mainland (Freyhof et al., 2014). Similarly, a study on Telestes pleurobipunctatus (Stephanidis 1939) revealed a high genetic differentiation between populations from different basins, suggesting the existence of a complex of species in the Ionian Sea slope (Buj et al., 2019). On the other hand, Knipowitschia goerneri Ahnelt 1991, which was believed to be restricted to a single lagoon system on Kerkira Island, is most probably much more widespread in the Ionian biogeographic region (Vanhove et al., 2016; Vukić et al., 2016, 2017). Finally, molecular analyses of the species of Squalius Bonaparte 1837 from the south of the Peloponnese uncovered a past hybridization between evolutionary very distant lineages, which led to a complete mitochondrial DNA introgression (Perea et al., 2016).

Among the most widespread fishes in southern Greece are members of the leuciscid minnow genus Pelasgus Kottelat \& Freyhof 2007, which is endemic to the southern Balkans. Out of the seven recognized species, three are present in southern Greece (Barbieri et al., 2015). The Evrotas minnow Pelasgus laconicus (Kottelat \& Barbieri 2004) occurs only in two river basins in the southern Peloponnese (Evrotas and headwaters of Alfios), while the Marathon minnow Pelasgus marathonicus (Vinciguerra 1921) and the Stymphalia minnow Pelasgus stymphalicus (Valenciennes 1844) are supposed to have large distribution ranges, even though a number of populations were only tentatively identified as belonging to these species (Kottelat and Barbieri, 2004; Kottelat and Freyhof, 2007). While $P$. stymphalicus occurs in a number of drainages in the southern part of the Ionian region (both on the mainland and on the Peloponnese), P. marathonicus inhabits rivers and streams of the Western Aegean region (Kottelat and Barbieri, 2004; Economou et al., 2007; Koutsikos et al., 2012; Barbieri et al., 2015). Both species are important biogeographic indicator species for the Western Aegean (P. marathonicus) and Ionian (P. stymphalicus) ecoregions (Vavalidis et al., 2019) and thus are of a great conservation importance. Nevertheless, no detailed study, genetic nor morphologic, which would include specimens of $P$. marathonicus or P. stymphalicus from multiple localities has been published. The aim of this work is to study the distribution and genetic diversity of populations of $P$. marathonicus and P. stymphalicus, based on recent samples comprehensively covering their expected ranges, and on molecular analyses of the mitochondrial marker cytochrome $b$.

\section{Material and methods}

One-hundred-twenty-five individuals were collected by electrofishing from 29 localities in southern Greece, extensively covering expected distribution ranges of P. marathonicus (48 individuals from eight river basins) and P. stymphalicus (77 individuals from twelve river basins; Tab. 1, Fig. 1; see Tabs. S1, S2 for details). Finclips were preserved in $96 \%$ ethanol for subsequent molecular analysis. Genomic DNA was extracted using the Geneaid ${ }^{\mathrm{TM}}$ DNA Isolation Kit (Tissue) (Geneaid Biotech). Individuals were genotyped by sequencing of the mitochondrial marker cytochrome $b(c y t b)$, which is widely used in population (e.g. Pascual et al., 2017; Buj et al., 2019), phylogenetic (e.g. Perea et al., 2010; Yang et al., 2015) and taxonomic studies (e.g. Buj et al., 2010; Barbieri et al., 2017).

Amplification was performed with a commercial kit (PPP Master Mix; Top-Bio) in a GeneTouch thermocycler (Hangzhou Bioer Technology Co. Ltd.). Cyt $b$ was amplified with the primers GluF and ThrR (Machordom and Doadrio, 2001) under the conditions described in Šanda et al. (2008).

PCR products were visualized on $1.5 \%$ agarose gel and purified by ethanol precipitation (Towner, 1991). Sequencing reactions were performed by Macrogen Service Centre Europe (Amsterdam, Netherlands). The primers used for sequencing were GluF, ThrR (Machordom and Doadrio, 2001), CB4-Glu and PhoxThr (Buj et al., 2019).

Sequences were visually checked and corrected in Chromas v2.6.6 (http://technelysium.com.au/wp/chromas/) and BioEdit v7.2.6 (Hall, 1999). The sequences of individual haplotypes were deposited in GenBank under accession numbers MT497285-MT497331. For each species one of the obtained haplotypes was already published (Schönhuth et al., 2018; Benovics et al., 2020; see Tab. S3). Sequences from more localities within the same river basin were pooled together per basin for all analyses. Sequences of individuals from the type localities were taken as a reference and all sequences were compared to the published $c y t b$ sequences of Pelasgus species (Zardoya and Doadrio, 1999; Freyhof et al., 2006; Perea et al., 2010; Schönhuth et al., 2018; Benovics et al., 2020; see Tab. S3). For this, a Bayesian Inference (BI) tree was constructed (Fig. S1). The appropriate model of nucleotide substitution was selected using jModelTest v2.1.7 (Darriba et al., 2012), based on Akaike Information Criterion (AIC). The selected model was GTR + I. BI was conducted in MrBayes v3.2.2 (Ronquist et al., 2012) with four independent MCMC runs for 3 million generations. Trees were sampled every 600 generations. The convergence of the runs was analyzed and visualized in Tracer v1.7.1 (Rambaut et al., 2018). The first $20 \%$ of sampled trees were discarded as burn-in and the remaining trees were used to construct a $50 \%$ majority-rule consensus tree. For phylogenetic analysis individual haplotypes were used. The sequences were collapsed to haplotypes in DnaSP v6.12.01 
Table 1. Sampling localities, number of analyzed individuals $(N)$, number of haplotypes $(h)$ and haplotype designation (haplotypes are numbered from 1 for each species).

\begin{tabular}{|c|c|c|c|c|c|}
\hline Species & River basin & No of sampled sites & $\mathrm{N}$ & $\mathrm{h}$ & Haplotypes \\
\hline \multirow{8}{*}{ P. marathonicus } & Xerias & 1 & 5 & 2 & Hap_1, hap_2 \\
\hline & Kifissos (Beotia) & 2 & 8 & 5 & Hap_3, hap_4, hap_5, hap_6, hap_7 \\
\hline & Erasinos & 1 & 5 & 2 & Hap_8, hap_9 \\
\hline & Kato Souli (Marathon) & 1 & 8 & 3 & Hap_10, hap_11, hap_12 \\
\hline & Kifissos (Athens) & 1 & 5 & 1 & Hap_8 \\
\hline & Pinios (Thessaly) & 1 & 5 & 4 & Hap_4, hap_13, hap_14, hap_15 \\
\hline & Sperchios & 2 & 4 & 4 & Hap_13, hap_15, hap_16, hap_17 \\
\hline & Assopos (Beotia) & 2 & 8 & 1 & Hap_18 \\
\hline \multirow{12}{*}{ P. stymphalicus } & Mornos & 3 & 7 & 4 & Hap_1, hap_2, hap_4, hap_5 \\
\hline & Evinos & 2 & 4 & 2 & Hap_3, hap_6 \\
\hline & Acheloos & 1 & 4 & 4 & Hap_3, hap_7, hap_8, hap_9 \\
\hline & Piros & 1 & 2 & 1 & Hap_10 \\
\hline & Kotichi & 1 & 4 & 4 & Hap_11, hap_12, hap_13, hap_14 \\
\hline & Pinios & 2 & 6 & 1 & Hap_14 \\
\hline & Alfios & 3 & 9 & 6 & Hap_15, hap_16, hap_17, hap_18, hap_19, hap_20 \\
\hline & Peristeras & 1 & 2 & 1 & Hap_21 \\
\hline & Pamissos & 1 & 5 & 2 & Hap_19, hap_22 \\
\hline & Milos & 1 & 3 & 1 & Hap_19 \\
\hline & Assopos (Peloponnese) & 1 & 5 & 4 & Hap_23, hap_24, hap_25, hap_26 \\
\hline & Stymphalia & 2 & 26 & 9 & $\begin{array}{l}\text { Hap_19, hap_22, hap_25, hap_26, hap_27, } \\
\text { hap_28, hap_29, hap_30, hap_31 }\end{array}$ \\
\hline
\end{tabular}

(Rozas et al., 2017). Delminichthys ghetaldii (Steindachner 1882) was used as outgroup. Inkscape v0.92.3 was used for editing the tree.

Intraspecific genetic diversity was estimated by calculating several DNA polymorphism measures in DnaSP v6.12.01 (Rozas et al., 2017): number of polymorphic sites $(S)$, nucleotide diversity $(\pi)$, number of haplotypes $(h)$ and haplotype diversity (Hd). MEGA v7.0.26 (Kumar et al., 2016) was used to calculate mean within and between population genetic distances (uncorrected p-distances). DnaSP (v6.12.01, Rozas et al., 2017) was further used for tests of neutrality (Tajima's and Fu and Li's tests), for sorting cyt $b$ haplotypes and to prepare input files for the Analysis of Molecular Variance (AMOVA). Haplotype networks were constructed in TCS v1.21 (Clement et al., 2000) based on statistical parsimony estimation (Templeton et al., 1992) with a $95 \%$ connection limit. Visualization and editing of the haplotype networks were performed in the web-based program tcsBU (TCS Beautifier; Santos et al., 2016) and Inkscape v0.92.3. Analysis of Molecular Variance (AMOVA), including fixation indices $\left(F_{\mathrm{STs}}\right)$ estimations, was performed in Arlequin v 3.5.2.2. (Excoffier and Lischer, 2010) executing 16,000 permutations. For the estimation of significance of pairwise $F_{\mathrm{STs}}$ a standard Bonferroni correction was applied. A number of genetically similar clusters within each species was inferred with Discriminant Analysis of Principal Components (DAPC) implemented in adegenet package v2.1.1 (Jombart, 2008) for $\mathrm{R}$ software (v3.6.1). DAPC is a multivariate approach which first transforms the data using a principal component analysis (PCA) and subsequently identifies clusters using discriminant analysis. Best-fit nucleotide substitution model was estimated independently for each species with jModelTest v2.1.7
(Darriba et al., 2012) and selected on the basis of Akaike information criterion (AIC) and Bayesian information criterion (BIC). Selected model (TN93 for both species) was used for inference of population demography applying the coalescent Bayesian Skyline Plot model (Drummond et al., 2005) implemented in BEAST v1.7.5 (Drummond et al., 2012). $C y t b$ evolutionary rate of $0.4 \%$ divergence per lineage per million years estimated for leuciscids (Perea et al., 2010) was applied with a strict clock model. Length of MCMC chain was 100 million and sampling every 10,000 generations. Results from three independent runs were combined using LogCombiner v1.7.5 (Drummond and Rambaut, 2007) with a burn-in of 20 million iterations $(20 \%)$ for each run. Tracer v1.7.1 (Rambaut et al., 2018) was used to assess the convergence of chains and to reconstruct Bayesian Skyline Plots.

\section{Results}

Forty-eight individuals were identified as $P$. marathonicus and 77 individuals as $P$. stymphalicus (see Tab. 1). The phylogenetic relationships of species of Pelasgus are shown in Figure S1. The minimum interspecific genetic distances on $c y t b$ between any pair of species of the genus Pelasgus was $3.75 \%$, and was found between $P$. stymphalicus and P. marathonicus (estimated from own data and published sequences from NCBI database, not shown). The maximum intraspecific differences in both investigated species in this work did not exceed $0.9 \%$. These results show a conspecific status of the investigated populations of each species. 


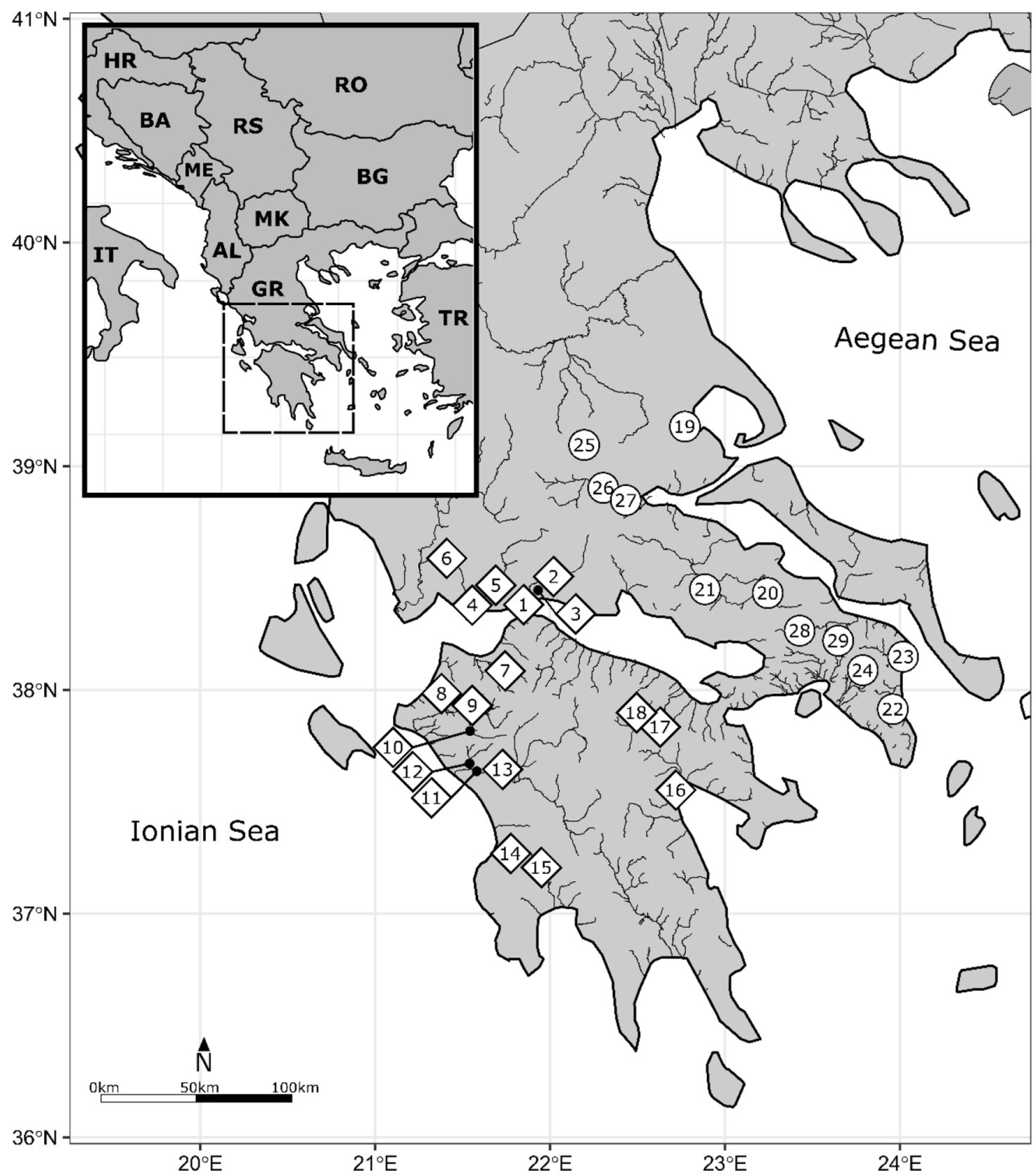

Fig. 1. Sampling sites. Pelasgus stymphalicus - $\diamond$ : 1,2,3-Mornos; 4,5-Evinos; 6-Acheloos; 7-Piros; 8-Kotichi Lake; 9,10-PiniosPeloponnese; 11,12,13-Alfios; 14-Peristeras; 15-Pamissos; 16-Milos; 17-Assopos-Peloponnese; 18-Stymphalia Lake. Pelasgus marathonicus - O: 19-Xerias; 20,21-Kifissos-Beotia; 22-Erasinos; 23-Kato Souli; 24-Kifissos-Athens; 25-Pinios-Thessaly; 26,27-Sperchios; 28,29-Assopos-Beotia. See Tabs S1, S2 for details.

\subsection{Pelasgus marathonicus}

A total of 48 sequences of $c y t b$, of 1140 bp length, were obtained for $P$. marathonicus. We revealed a high number of cyt $b$ haplotypes $(h=18)$ and haplotype diversity $(\mathrm{Hd}=0.93$; Tab. 2) within this species. The tests of neutrality were all negative, but nonsignificant. Bayesian Skyline Plot reconstruction showed a slightly increasing population size over time, with a recent tendency to decrease, dated to approximately 10 thousand years ago (Fig. 2a).
Table 2. Measures of genetic diversity of Pelasgus marathonicus and P. stymphalicus. $\mathrm{N}$ - number of sequences; $\pi$ - nucleotide diversity; $\mathrm{S}$ - number of polymorphic sites; $\mathrm{h}$ - number of haplotypes; $\mathrm{Hd}$ - haplotype diversity.

\begin{tabular}{llllll}
\hline & $\mathrm{N}$ & $\pi$ & $\mathrm{S}$ & $\mathrm{h}$ & $\mathrm{Hd}$ \\
\hline P. marathonicus & 48 & 0.00297 & 19 & 18 & 0.93 \\
P. stymphalicus & 77 & 0.00370 & 39 & 31 & 0.93 \\
\hline
\end{tabular}



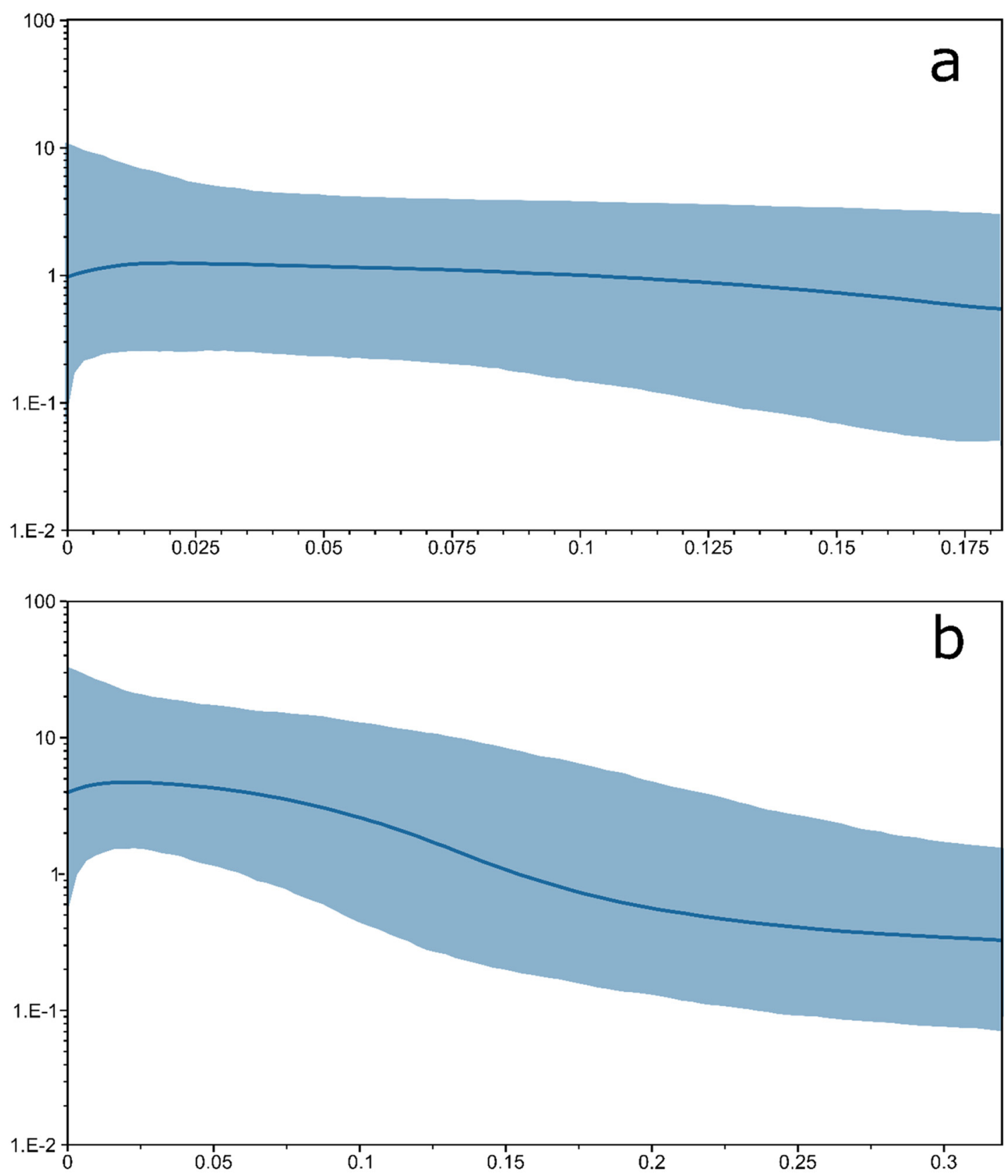

Fig. 2. Bayesian skyline plot representing historical demographic trends in: (a) Pelasgus marathonicus, and (b) P. stymphalicus. The course of the graph illustrates fluctuation of the population size from recent to the coalescence (left to the right). Time on the $x$-axis in million years ago. $Y$-axis shows effective population size $\times$ generation time; in logarithmic scale. Solid middle line shows the median estimate and the blue shaded area represents $95 \%$ highest probability density limits.

The proportion of private haplotypes was noteworthy (14 out 18 , i.e. $77.8 \%$, Fig. 3 ). The private haplotypes were present in populations from all drainages with the exception of Kifissos (Athens). Within the native range, only the populations from Kifissos (Athens) and Erasinos shared one haplotype. The supposedly introduced population from Pinios (Thessaly) shared one haplotype with Kifissos (Beotia) and two with Sperchios populations. The only populations with a single haplotype were those from Assopos (Beotia) and Kifissos (Athens); both these populations occur in a limited part of very small isolated basins. Despite the fact that the haplotypes from each population were closely related and grouped together, the haplotype network reconstruction did not show any broader geographic structure. DAPC showed that apart from the Assopos (Beotia) population, all P. marathonicus populations clustered together (Fig. S2). Genetic distances between populations ranged from $0.15 \%$ to $0.6 \%$ (Tab. 3). The highest genetic distance values were revealed between Assopos (Beotia) and Erasinos populations, Assopos (Beotia) and Kifissos (Athens) populations, despite the geographic proximity of these drainages, and Erasinos and Kifissos (Beotia). Genetic distances within groups were low 
and ranged from zero (Kifissos-Athens and Assopos-Beotia) to $0.18 \%$ (Pinios-Thessaly) (Tab. 3). The mean genetic distance for the whole $P$. marathonicus dataset was $0.3 \%$, while the maximum distance was $0.62 \%$.

AMOVA showed that the genetic variance is evenly distributed among (52\%) and between populations (48\%) of P. marathonicus (Tab. 4), with a high and significant $F_{\mathrm{ST}}$ value
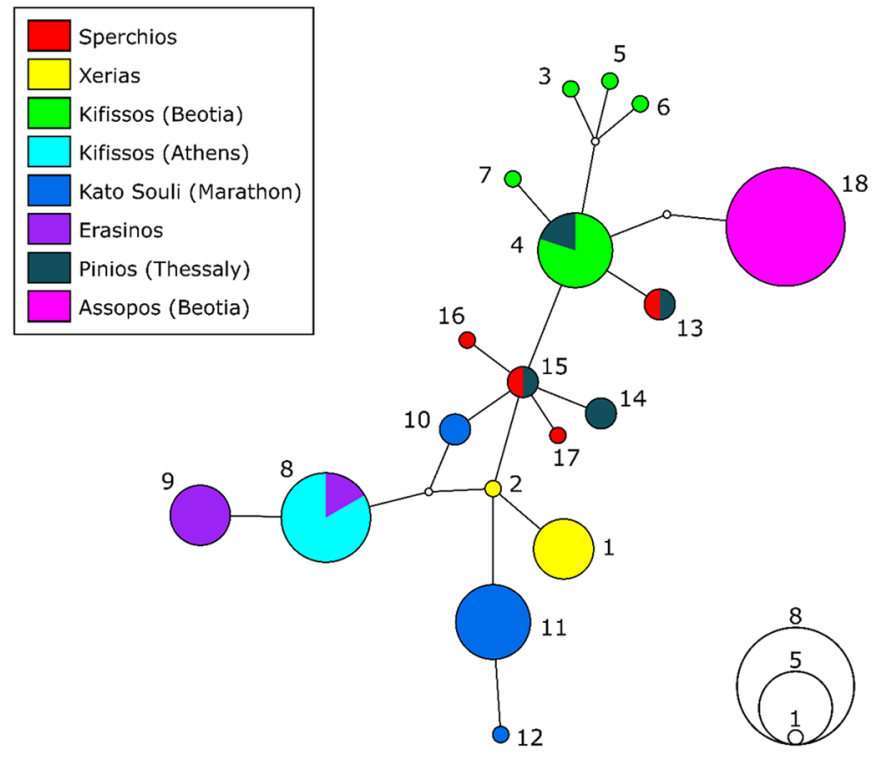

Fig. 3. Haplotype network reconstruction of cytochrome $b$ sequences of Pelasgus marathonicus (statistical parsimony method, 95\% connection limit). Numbers designate individual haplotypes. The maximum number of steps connecting parsimoniously two haplotypes is indicated (one line between two haplotypes being one mutational step). Missing intermediate haplotypes are shown as small white circles.
$\left(F_{\mathrm{ST}}=0.52\right)$, indicating a pronounced genetic differentiation of the populations. Pairwise $F_{\mathrm{STs}}$ between populations also indicated a pronounced genetic differentiation (with the exception of the population pair Sperchios/Pinios-Thessaly), which was significant in half of the cases (Tab. 5).

\subsection{Pelasgus stymphalicus}

A total of 77 sequences of $c y t b$ of 1140 bp length were obtained for $P$. stymphalicus. Our results revealed slightly higher nucleotide diversity within $P$. stymphalicus $(\pi=0.0037)$ than within $P$. marathonicus, and equal haplotype diversity $(\mathrm{Hd}=0.93$; Tab. 2). The number of obtained haplotypes was 31 . All tests of neutrality were negative, of which Fu and Li's tests were significant (Fu and Li's $D=-2.39$, Fu and Li's $F=-2.47)$. These results could indicate either population expansion or a selective sweep. Bayesian Skyline Plot reconstruction showed a gradual population growth over time, with a recent tendency to decrease, about 20 thousand years ago (Fig. 2b).

Haplotype network showed an interesting geographic pattern (Fig. 4). There were two haplogroups separated by a minimum of two mutations. The first haplogroup corresponded to the populations in the southern and eastern Peloponnese (Stymphalia Lake, Milos, Assopos-Peloponnese, Peristeras and Pamissos river basins), and the second corresponded to the populations on the mainland (Acheloos, Evinos and Mornos basins) and the adjacent north-western Peloponnese (Piros, Pinios and Kotichi basins). Interestingly, the haplotypes from Alfios were very divergent and were present in both haplogroups. The proportion of private haplotypes was very high ( 25 out of 31 , i.e. $80.6 \%$ ) and the private haplotypes were present in the populations from all drainages, with the exception of Pinios-Peloponnese population (a single haplotype shared with Kotichi population) and Pamissos (one

Table 3. Mean genetic distances for populations of Pelasgus marathonicus based on cytochrome b sequences (uncorrected p-distances), in \%. Within group distances are on diagonal in bold.

\begin{tabular}{llllllll}
\hline & Xer & KifB & Era & Kat & KifA & Spe & Pin \\
\hline Xerias & $\mathbf{0 . 0 3 5}$ & & & & & & \\
Kifissos (Beotia) & 0.32 & $\mathbf{0 . 1 3 5}$ & & & & & \\
Erasinos & 0.32 & 0.5 & $\mathbf{0 . 0 3 5}$ & & & & \\
Kato Souli (Marathon) & 0.19 & 0.33 & 0.32 & $\mathbf{0 . 1 3 5}$ & & & \\
Kifissos (Athens) & 0.25 & 0.43 & 0.07 & 0.25 & $\mathbf{0}$ & & \\
Sperchios & 0.25 & 0.21 & 0.42 & 0.25 & 0.35 & $\mathbf{0 . 1 7 5}$ & $\mathbf{0 . 1 4 0}$ \\
Pinios (Thessaly) & 0.25 & 0.18 & 0.42 & 0.25 & 0.35 & 0.15 & 0.28 \\
Assopos (Beotia) & 0.42 & 0.25 & 0.6 & 0.43 & 0.53 & 0.31 & $\mathbf{0}$ \\
\hline
\end{tabular}

Table 4. Partitioning of genetic variance, in \%, and fixation indices $\left(F_{\mathrm{ST}}\right)$ for Pelasgus marathonicus and P. stymphalicus, based on cytochrome $b$ sequences.

\begin{tabular}{|c|c|c|c|}
\hline & & P. marathonicus & P. stymphalicus \\
\hline & Among populations & 52.11 & 58.34 \\
\hline Partitioning of genetic variance & Within populations & 47.89 & 41.66 \\
\hline Genetic differentiation & $F_{\mathrm{ST}}$ & 0.521 & 0.583 \\
\hline
\end{tabular}


N. Viñuela Rodríguez et al.: Knowl. Manag. Aquat. Ecosyst. 2020, 421, 27

Table 5. Pairwise $F_{\mathrm{ST}}$ between populations of Pelasgus marathonicus based on cytochrome $b$ sequences. Significant values (at $\alpha=0.05 /$ number of pairs) indicated in bold.

\begin{tabular}{|c|c|c|c|c|c|c|c|}
\hline & Xer & KifB & Era & Kat & KifA & Pin & Spe \\
\hline \multicolumn{8}{|l|}{ Xerias } \\
\hline Kifissos (Beotia) & 0.703 & & & & & & \\
\hline Erasinos & 0.889 & 0.806 & & & & & \\
\hline Kato Souli (Marathon) & 0.508 & 0.591 & 0.706 & & & & \\
\hline Kifissos (Athens) & 0.929 & 0.805 & 0.750 & 0.677 & & & \\
\hline Pinios (Thessaly) & 0.643 & 0.246 & 0.792 & 0.457 & 0.800 & & \\
\hline Sperchios & 0.603 & 0.276 & 0.77 & 0.405 & 0.781 & 0 & \\
\hline Assopos (Beotia) & 0.969 & 0.733 & 0.979 & 0.843 & 1.000 & 0.809 & 0.815 \\
\hline
\end{tabular}

\begin{tabular}{|l|l|}
\hline$\square$ & Kotichi Lake \\
& Pinios (Peloponnese) \\
$\square$ & Peristeras \\
$\square$ & Pamissos \\
$\square$ & Evinos \\
$\square$ & Acheloos \\
$\square$ & Milos \\
$\square$ & Assopos (Peloponnese) \\
$\square$ Alfios \\
$\square$ Stymphalia \\
$\square$ Piros \\
$\square$ Mornos \\
\hline
\end{tabular}

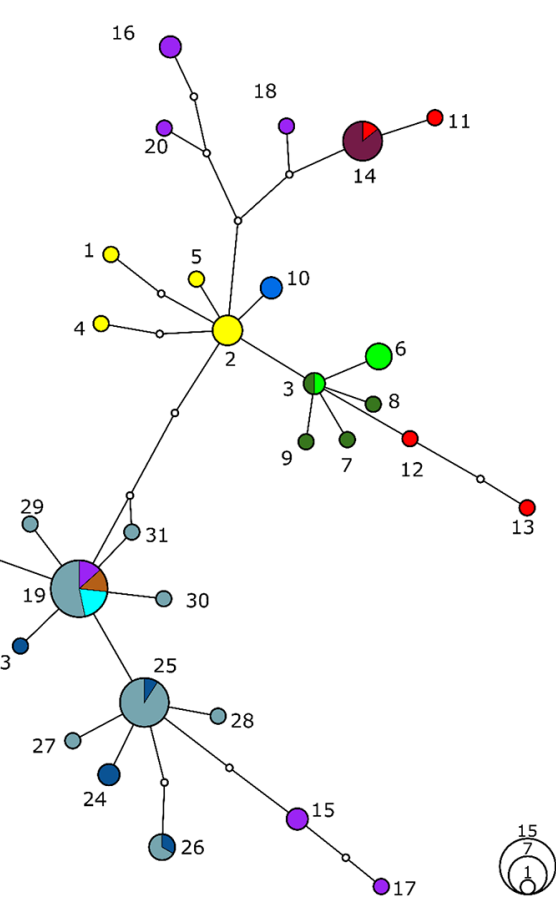

Fig. 4. Haplotype network reconstruction of cytochrome b sequences of Pelasgus stymphalicus (statistical parsimony method, 95\% connection limit). Numbers designate individual haplotypes. The maximum number of steps connecting parsimoniously two haplotypes is indicated (one line between two haplotypes being one mutational step). Missing intermediate haplotypes are shown as small white circles.

haplotype shared with Stymphalia and the other with Stymphalia, Alfios and Milos populations). In the northwestern haplogroup two haplotypes were shared between two different populations: Evinos/Acheloos and abovementioned Pinios-Peloponnese/Kotichi; in the south-eastern haplogroup, four haplotypes were shared (see Fig. 4). There was a particular geographical pattern within the north-western haplogroup, where the haplotypes of the pairs of populations grouped together: Piros (Peloponnese) and Mornos (mainland), Evinos and Acheloos (both mainland) and haplotypes 11 and 14 from Kotichi and Pinios (both Peloponnese). The haplotypes from
Kotichi population were diversified: two other haplotypes (12 and 13) were most similar to the Evinos/Acheloos group (mainland). This could indicate a secondary contact of the populations from the mainland and north-western Peloponnese during the Pleistocene. Within the south-eastern haplogroup there was no geographic pattern.

DAPC divided $P$. stymphalicus populations into four clusters: (1) Kotichi and Pinios-Peloponnese, (2) Evinos and Acheloos, (3) Mornos and Piros populations and (4) the remaining populations (Fig. S3). These results line up with those of the haplotype network reconstruction (Fig. 4). The mean genetic distances ( $p$-distances) between populations ranged from $0.1 \%$ to $0.8 \%$, being the highest between Peristeras and Kotichi and Pinios-Peloponnese populations and the lowest for the pairs of populations Acheloos/Evinos, Milos/Pamissos, Stymphalia/Pamissos, Stymphalia/Milos (Tab. 6). In general, the high $p$-distances were detected between populations from one haplogroup versus populations from the other haplogroup. Genetic distances within populations ranged from 0 (Piros, Pinios-Peloponnese, Milos) to $0.5 \%$ (Alfios basin), see Table 6 . A high within population distance was also observed for Kotichi $(0.42 \%)$. The mean genetic distance for the whole $P$. stymphalicus dataset was $0.4 \%$ and the maximum difference was $0.89 \%$.

AMOVA showed that genetic variance in $P$. stymphalicus was higher among (58\%) than between populations (42\%) and the $F_{\mathrm{ST}}$ of 0.58 indicated a pronounced genetic differentiation of the populations (Tab. 4). Also pairwise $F_{\mathrm{STs}}$ indicated a pronounced genetic differentiation between the populations (with the exception of Assopos-Peloponnese vs. Pamissos and Milos), but were, however, significant only for most comparisons of Assopos-Peloponnese and two of Mornos populations (Tab. 7).

\section{Discussion}

Both investigated Pelasgus species have particular distribution patterns (Fig. 1), probably given not only by the geological history of the area but also by their ability to inhabit very small streams, isolated spring-fed lentic waters and wetlands, unlike most other native fish species in the area. Pelasgus generally inhabits slow-flowing and nearly stagnant waters with abundant vegetation from coastal wetlands to upland plateaus. It is able to survive periods of draught in river- 
N. Viñuela Rodríguez et al.: Knowl. Manag. Aquat. Ecosyst. 2020, 421, 27

Table 6. Mean genetic distances between populations of Pelasgus stymphalicus based on cytochrome b sequences (uncorrected p-distances), in \%. Within group distances are on diagonal in bold.

\begin{tabular}{|c|c|c|c|c|c|c|c|c|c|c|c|c|}
\hline & Mor & Evi & Ach & Pir & Kot & Pin & Alf & Per & Pam & Mil & Ass & Sty \\
\hline Mornos & 0.125 & & & & & & & & & & & \\
\hline Evinos & 0.22 & 0.044 & & & & & & & & & & \\
\hline Acheloos & 0.22 & 0.13 & 0.132 & & & & & & & & & \\
\hline Piros & 0.15 & 0.24 & 0.24 & $\mathbf{0}$ & & & & & & & & \\
\hline Kotichi & 0.35 & 0.35 & 0.35 & 0.37 & 0.424 & & & & & & & \\
\hline Pinios (Peloponnese) & 0.33 & 0.42 & 0.42 & 0.35 & 0.29 & $\mathbf{0}$ & & & & & & \\
\hline Alfios & 0.43 & 0.53 & 0.52 & 0.46 & 0.6 & 0.52 & 0.497 & & & & & \\
\hline Peristeras & 0.59 & 0.68 & 0.68 & 0.61 & 0.81 & 0.79 & 0.62 & $\mathbf{0}$ & & & & \\
\hline Pamissos & 0.38 & 0.47 & 0.47 & 0.40 & 0.60 & 0.58 & 0.41 & 0.21 & 0.053 & & & \\
\hline Milos & 0.33 & 0.42 & 0.42 & 0.35 & 0.55 & 0.53 & 0.36 & 0.26 & 0.05 & $\mathbf{0}$ & & \\
\hline Assopos (Peloponnese) & 0.48 & 0.58 & 0.58 & 0.51 & 0.71 & 0.68 & 0.47 & 0.42 & 0.21 & 0.16 & 0.193 & \\
\hline Stymphalia & 0.40 & 0.49 & 0.49 & 0.43 & 0.63 & 0.60 & 0.41 & 0.34 & 0.13 & 0.08 & 0.16 & 0.112 \\
\hline
\end{tabular}

Table 7. Pairwise $F_{\mathrm{ST}}$ between populations of Pelasgus stymphalicus based on cytochrome $b$ sequences. Significant values (at $\alpha=0.05 /$ number of pairs) indicated in bold.

\begin{tabular}{|c|c|c|c|c|c|c|c|c|c|c|c|}
\hline & Mor & Evi & Ach & Pir & Kot & Pin & Alf & Per & Pam & Mil & Ass \\
\hline \multicolumn{12}{|l|}{ Mornos } \\
\hline Evinos & 0.367 & & & & & & & & & & \\
\hline Acheloos & 0.564 & 0.866 & & & & & & & & & \\
\hline Piros & 0.409 & 0.611 & 0.333 & & & & & & & & \\
\hline Kotichi & 0.793 & 1.000 & 0.960 & 0.879 & & & & & & & \\
\hline Pinios (Peloponnese) & 0.288 & 0.229 & 0.333 & 0.208 & 0.369 & & & & & & \\
\hline Alfios & 0.823 & 1.000 & 0.952 & 0.857 & 1.000 & 0.626 & & & & & \\
\hline Peristeras & 0.246 & 0.188 & 0.37 & 0.314 & 0.453 & 0.215 & 0.377 & & & & \\
\hline Pamissos & 0.727 & 1.000 & 0.937 & 0.814 & 1.000 & 0.553 & 1.000 & 0.114 & & & \\
\hline Milos & 0.682 & 0.71 & 0.778 & 0.711 & 0.873 & 0.581 & 0.653 & 0.221 & 0.265 & & \\
\hline Assopos (Peloponnese) & 0.714 & 0.763 & 0.797 & 0.767 & 0.853 & 0.73 & 0.703 & 0.366 & 0.072 & 0.091 & \\
\hline Stymphalia & 0.749 & 0.897 & 0.896 & 0.814 & 0.96 & 0.638 & 0.806 & 0.251 & 0.388 & 0.417 & 0.291 \\
\hline
\end{tabular}

bed pools, wells and springs (Economou et al., 1999; Economou, 2000) and although it prefers freshwater, it can potentially survive for short periods in brackish conditions with salinity up to $12-13 \%$ (Bianco and Nordlie, 2008). Their ecology and ability to stand adverse conditions most probably enabled $P$. marathonicus and $P$. stymphalicus to have a wide distribution in seasonally semi-arid areas.

The range of $P$. stymphalicus was suggested to include most of the Ionian and a few Aegean drainages on the Peloponnese, including endorheic Stymphalia Lake (type locality), and the rivers in the south-west of mainland, in the Ionian Sea slope, from the Mornos to two small drainages in the south-eastern part of the Amvrakikos Gulf, including Lefkada Island (Kottelat and Barbieri, 2004; Economou et al., 2007; Koutsikos et al., 2012; Barbieri et al., 2015). However, many of these populations were ascribed only tentatively to $P$. stymphalicus, and the verification of their conspecific status has been awaiting further studies (Kottelat and Freyhof, 2007). We confirmed the presence of $P$. stymphalicus in the majority of these drainages. Moreover, we have found it for the first time in the Assopos (north-eastern Peloponnese), where earlier surveys failed to find it (Economou et al., 1999, 2007). To summarize, based on our results, $P$. stymphalicus occurs in the
Ionian region, from the Acheloos basin on the mainland to the Pamissos river in the south-western Peloponnese, and in the eastern Peloponnese (Aegean Sea slope), in the lowland Argolid's spring-fed wetlands (in our samples represented by Milos population). However, the status of a small number of populations along the Akarnanian coast was not possible to examine (Astakos, Lefkada, small drainages in the southeastern part of the Amvrakikos Gulf), so the exact distribution limit at the north-western edge of the distribution range is still undefined. Moreover, the identity of Pelasgus from the endorheic Kandila springs in the north-east of the Peloponnese (adjacent to the Stymphalia drainage), where another species has been assumed to be present (Kottelat and Barbieri, 2004), needs further investigation.

Furthermore, we were not able to confirm the occurrence of Pelasgus in several small drainages in the Peloponnese which lie within the range of the species, despite our sampling effort (e.g. Neda, Vouraikos, Selinous, Taka Lake). Importantly, in several small basins in the Peloponnese (Peristeras, Assopos, Piros) this species was found in very low numbers, which may indicate that it is under threat.

A particular situation in the Alfios basin on the Peloponnese, revealed by Kottelat and Barbieri (2004), was 
confirmed: the populations from the lower part of the basin belong to $P$. stymphalicus, whereas the populations from the headwater part belong to $P$. laconicus (genetic divergence between these species $10.2 \%$, own data). This is probably a result of past tectonic or orogenetic events, which led to river captures in headwaters of the Alfios and Evrotas river basins, which, at the same time separated the population of P. laconicus currently occurring in the upper Alfios from its remaining populations in the Evrotas river. Furthermore, the diversity and divergence of haplotypes within the Alfios population of $P$. stymphalicus may indicate past river capture events which enabled a connection of the contemporary tributaries of Alfios, which had previously belonged to different drainages and hosted genetically distant populations. The affinity of the populations of $P$. stymphalicus from Evinos, Acheloos and Kotichi Lake, and the populations from Mornos and Piros drainages (Fig. 4) can be explained by the Pleistocene sea level regressions (Perissoratis and Conispoliatis, 2003). Such regressions allowed the connection of the rivers on the mainland and on the Peloponnese, a phenomenon that enabled contact between the populations. This is in accordance with a very similar pattern that has been observed in the distribution of other freshwater fish species inhabiting this region (e.g. Luciobarbus albanicus (Steindachner 1870) or Tropidophoxinellus hellenicus (Stephanidis 1971), Economou et al., 2007). Acheloos and Evinos populations of Pelasgus appear to be closely related, and even share one haplotype (Fig. 4). Durand et al. (1999) suggested a connection of both drainages during the Late Pleistocene, and our results support that hypothesis. The divergence of the haplotypes from Kotichi can indicate a secondary contact between the population from the Peloponnese (haplotypes 14 and 11 grouped with the haplotype from the Pinios population) and the mainland (haplotypes 12 and 13 were similar to the Evinos/Acheloos group, see Fig. 4).

Analysed samples of Pelasgus marathonicus cover almost all known populations of the species, and include specimens from the type locality, Kato Souli in Schinias-Marathon wetland in Attiki. We confirmed that all investigated populations, which were previously supposed to belong to this species, although some of them only tentatively (Kottelat and Barbieri, 2004; Economou et al., 2007; Koutsikos et al., 2012; Barbieri et al., 2015), are conspecific. The species range spans from the Erasinos drainage, just south of Athens, up to the Xerias basin in the Pagasitikos Gulf. Pelasgus marathonicus was found even in the Beotian Assopos drainage, where it had been considered possibly extirpated (Economou et al., 2007). Furthermore, a population of Pelasgus from the Thessalian Pinios river drainage, considered to be recently introduced (Koutsikos et al., 2012), was shown to be $P$. marathonicus. We were not able to trace the exact origin of the introduced population, because haplotypes present in the Pinios population are shared with both Sperchios and Kifissos (Beotia) populations. More samples from all basins should be tested to reveal the path of introduction.

The only known population of $P$. marathonicus which we were not able to analyse is the one from central-western Euboea Island (reported by Barbieri et al., 2015). Although this population is virtually within the range of the species, its identity needs further research, as other freshwater fishes from Euboea in fact show affinity not to the nearby occurring species, but to populations from geographically distant areas (Barbus Daudin 1805 to Ionian populations: Tsigenopulos and Berrebi, 2000, see further discussion; Squalius to eastern Aegean populations: Zardoya and Doadrio, 1999). Further, Pelasgus may occur in some very small unsampled basins.

\subsection{Biogeographical insights}

Several biogeographic regions were recognised in the southern Balkans based on the distribution of fish species (Zogaris et al., 2009; Oikonomou et al., 2014). Southern Greece comprises two such regions, Ionian and Western Aegean. The extent of both regions slightly varies according to different authors (Zogaris et al., 2009; Oikonomou et al., 2014; Zogaris and Economou, 2017; Vavalidis et al., 2019). Recent molecular genetic studies conducted on several fish species suggest that further subdivision of the Ionian region is possible, dividing it to southern and northern subregion, with a boundary immediately south of the Amvrakikos Gulf (see overview in Buj et al., 2019). A part of the ichthyofauna of the southern Ionian subregion actually shows affinities to that of the Western Aegean region. Pelasgus stymphalicus (southern Ionian region) and P. marathonicus (Aegean region) are a pair of sister species (Schönhuth et al., 2018). The same relationship was found in other primary freshwater fishes from these regions, i.e. in the genus Rutilus Rafinesque 1820 (Ketmaier et al., 2008; Perea et al., 2010; Geiger et al., 2014; Schönhuth et al., 2018), Telestes Bonaparte 1840 (Perea et al., 2010; Geiger et al., 2014; Buj et al., 2017; Schönhuth et al., 2018) and for some species of Barbus (Barbus peloponnesius Valenciennes 1842 and Barbus euboicus Stephanidis 1950, see Tsigenopoulos and Berrebi, 2000). On the other hand, species of other genera present in both areas are not closely related. This applies to Luciobarbus Heckel 1843 (Yang et al., 2015), Squalius (Perea et al., 2010) and Scardinius Bonaparte 1837 (Ketmaier et al., 2004; Perea et al., 2010). These differences in the evolutionary relationships within different genera are most probably a consequence of a very complex geological history of the area, in a combination with the different life history traits of the species/genera and repeated episodes of colonization of the area.

The genetic diversity of the endemic fishes from this area was studied only in a few species and showed different patterns than the ones revealed here for Pelasgus. For the Western Aegean region, no comparative study of such extent is available. Pelasgus marathonicus is the most widespread fish species in this region, having a much broader distribution than any other species occurring here. Moreover, although most of its populations have private haplotypes, these are closely related. On the contrary, other endemic species from the Western Aegean region have much smaller distribution ranges, they occur in a single (i.e. Alburnoides economoui Barbieri, Vukić, Šanda \& Zogaris 2017, Rutilus ylikiensis Economidis 1991, Scardinius graecus Stephanidis, 1937) or a few drainages (i.e. Luciobarbus graecus (Steindachner 1895), Telestes beoticus (Stephanidis 1939)) (Economou et al., 2007; Barbieri et al., 2015, 2017), and their genetic diversity has not been studied yet.

Pelasgus stymphalicus is also a widespread species. None of the other species from the southern part of the Ionian region has such a large range (Economou et al., 2007). A recent study 
has revealed a high genetic diversity in T. pleurobipunctatus, a species that has been previously considered a single species widely distributed in the whole Ionian region. In fact, T. pleurobipunctatus comprises several distinct evolutionary units which probably represent distinct species (Buj et al., 2019). Within its overlapping range with P. stymphalicus, three evolutionary units of T. pleurobipunctatus occur. Interestingly, there is a similar pattern in the close relationships between Telestes populations from the mainland (Evinos river) and the north-western Peloponnese (Kotichi and Pinios basins) to the one observed in Pelasgus, suggesting a connection of these areas during the Pleistocene glacial periods (Buj et al., 2019). On the other hand, while the populations of Pelasgus from Acheloos and Evinos are genetically related and even share one haplotype, the populations of Telestes from these drainages form two distinct clades, differing on $c y t$ by $3.5 \%$ (Buj et al., 2019). Also Squalius displays higher diversity in the overlapping range with $P$. stymphalicus. Durand et al. (1999) observed differentiation between Squalius from Alfios and a clade which includes Squalius from Peloponnesian Pinios and mainland Evinos and Acheloos. Further, Perea et al. (2016) found divergence between Squalius from Alfios and Stymphalia Lake. Thus P. stymphalicus seems to be unique in its genetic homogeneity over a large area, compared with other widespread fish species.

\subsection{Threats and conservation}

The IUCN status of $P$. marathonicus is near threatened (NT), while that of $P$. stymphalicus is least concern (LC). However, our results suggest a recent decreasing tendency of the effective population sizes in both studied species. This suggests that populations of both species could be sensitive to anthropogenic pressure. Main threats to freshwater ecosystems are habitat loss, introduction of alien species and pollution (Collen et al., 2014). The human-induced hydrological degradation, construction of dams and other dispersal barriers and canalization of water bodies entail the destruction of the habitat of Pelasgus species. A spread of alien species, especially Gambusia holbrooki Girard 1859, has long been shown to be a serious problem for this and other small-sized endemic fishes in Greece (Economidis 2009; Kalogianni et al., 2019). Furthermore, since fish translocations are on the rise (Koutsikos et al., 2019), an insidious threat is hybridization with other Pelasgus species, which can be traced by the use of appropriate nuclear markers. Cases of hybridization due to translocation were already observed in some Pelasgus populations (own unpublished data). Pelasgus is not a species of interest for recreational fishing, neither is it used as live bait. Its translocation is unintentional, and happens by translocation of species of commercial or recreational interest, with which individuals of Pelasgus are mixed (Kottelat and Barbieri, 2004).

Although distribution ranges of the studied species seem to be relatively large, Pelasgus are small-sized fishes with limited dispersal abilities, and given the type of habitat they inhabit (usually small lowland streams, with slow-flowing water), they are susceptible also to droughts caused by regional climate variation and global climate change. Climate change predictions forecast increased desiccation of perennial flowing water bodies and wetlands in the region (Kokkoris et al., 2019).

It is alarming that Pelasgus populations were not found in our and other recent surveys in several river basins that lie within their distribution ranges (e.g. Economou et al., 2016; Zogaris et al., 2018). The presence of private $c y t b$ haplotypes in populations of both species points to the uniqueness and vulnerability of each population. Populations with lower genetic diversity could have less chances of survival due to a small effective population size, and due to a smaller capacity to adapt to changing environmental conditions (Buj et al., 2015). It is of great importance to protect the species as a whole, but it should not be overlooked that units below species level may be of exceptional relevance for the future survival of the species. As the genetic structure of all populations from each river basin is distinct, populations should be considered individually. A strict protection of the rivers, lowland springs and wetlands where $P$. stymphalicus and $P$. marathonicus occur is of a great importance. The conservation status of both species should be re-evaluated. Of special conservation relevance is the Western Aegean ecoregion, being already considered a species-poor and with many perennial river reaches and wetlands under threat.

\section{Supplementary Material}

\section{Supplementary Tables S1 to S3.}

The Supplementary Material is available at https:/www.kmaejournal.org/10.1051/kmae/2020019/olm.

Acknowledgements. This project was financially supported by the Grant Agency of Charles University project no. 1052217. RS received support by the Ministry of Culture of the Czech Republic (DKRVO 2019-2023/6.IV.b National Museum, 00023272) and JV by institutional resources of the Ministry of Education, Youth, and Sports of the Czech Republic. SZ was funded by the Natura 2000 Ichthyofauna project (contracted to HCMR by N. Anagnopoulos/APC), collecting was conducted under Hellenic Ministry of Environment licence no. 220965/ 2583/22-8-2011. Further specimens were collected through combined fish parasitological research in collaboration with the Zoological Museum of the University of Athens under licence no. 161450/2422/25-9-2017. We thank A. Legakis and HCMR scientists who supported this work, especially D. Kommatas, L. Vardakas and A.N. Economou. We are grateful to the three anonymous reviewers for their constructive comments which helped improving this manuscript.

\section{References}

Barbieri R, Vukić J, Šanda R, Kapakos Y, Zogaris S. 2017. Alburnoides economoui, a new species of spirlin from Central Greece and redescription of Alburnoides thessalicus (Actinopterygii: Cyprinidae). Biologia 72: 1075-1088.

Barbieri R, Zogaris S, Kalogianni E, Stoumboudi MT, Chatzinikolaou Y, Giakoumi S, Kapakos Y, Kommatas D, Koutsikos N, Tachos V, Vardakas L, Economou AN. 2015. Freshwater fishes and Lampreys of Greece: An annotated checklist. Monographs on Marine 
Sciences No. 8, Hellenic Centre for Marine Research, Athens, Greece, $136 \mathrm{p}$.

Benovics M, Desdevises Y, Šanda R, Vukić J, Šimková A. 2020. Cophylogenetic relationships between Dactylogyrus (Monogenea) ectoparasites and endemic cyprinoids of the north-eastern European peri-Mediterranean region. J Zool Syst Evol Res 58: $1-21$.

Bianco PG, Nordlie F. 2008. The salinity tolerance of Pseudophoxinus stymphalicus (Cyprinidae) and Valencia letourneuxi (Valenciidae) from western Greece suggests a revision of the ecological categories of freshwater fishes. Ital J Zool 75: 285-293.

Buj I, Ćaleta M, Marčić Z, Šanda R, Vukić J, Mrakovčić M. 2015. Different histories, different destinies-impact of evolutionary history and population genetic structure on extinction risk of the Adriatic spined loaches (genus Cobitis; Cypriniformes, Actinopterygii). PLOS ONE 10: e0131580.

Buj I, Marčić Z, Ćaleta M, Šanda R, Geiger MF, Freyhof J, Vukić J. 2017. Ancient connections among the European rivers and watersheds revealed from the evolutionary history of the genus Telestes (Actinopterygii; Cypriniformes). PloS ONE 12: e0187366.

Buj I, Šanda R, Zogaris S, Freyhof J, Geiger MF, Vukić J. 2019. Cryptic diversity in Telestes pleurobipunctatus (Actinopterygii; Leuciscidae) as a consequence of historical biogeography in the Ionian Freshwater Ecoregion (Greece, Albania). Hydrobiologia 835: 147-163.

Buj I, Vukić J, Šanda R, Perea S, Ćaleta M, Marčić Z, Bogut I, Povž M, Mrakovčić M. 2010. Morphological comparison of bleaks (Alburnus, Cyprinidae) from the Adriatic Basin with the description of a new species. Folia Zool 59: 129-141.

Clement M, Posada D, Crandall KA. 2000. TCS: A computer program to estimate gene genealogies. Mol Ecol 9: 1657-1659.

Collen B, Whitton F, Dyer EE, Baillie JEM, Cumberlidge N, Darwall WRT, Pollock C, Richman NI, Soulsby AM, Böhm M. 2014. Global patterns of freshwater species diversity, threat and endemism. Glob Ecol Biogeogr 23: 40-51.

Darriba D, Taboada GL, Doallo R, Posada, D. 2012. jModelTest 2: more models, new heuristics and parallel computing. Nat Methods 9: 772-772.

Drummond AJ, Rambaut A. 2007. BEAST: Bayesian evolutionary analysis by sampling trees. BMC Evol Biol 7: 214.

Drummond AJ, Rambaut A, Shapiro B, Pybus OG. 2005. Bayesian coalescent inference of past population dynamics from molecular sequences. Mol Biol Evol 22: 1185-1192.

Drummond AJ, Suchard MA, Xie D, Rambaut A. 2012. Bayesian phylogenetics with BEAUti and the BEAST 1.7. Mol Biol Evol 29: 1969-1973.

Durand JD, Templeton AR, Guinand B, Imsiridou A, Bouvet Y. 1999. Nested clade and phylogeographic analyses of the chub, Leuciscus cephalus (Teleostei, Cyprinidae), in Greece: implications for Balkan Peninsula biogeography. Mol Phylogenet Evol 13: 566-580.

Economidis PS. 2009. Fishes of inland waters. In Legakis A, Maragou P, eds. Red Data Book of Threatened Animals of Greece, Hellenic Zoological Society, Athens, 86-159. (In Greek).

Economou AN. 2000. Pseudophoxinus stymphalicus: a "successful" fish species of the freshwaters of Greece, $9^{\text {th }}$ Panhellenic Ichthyological Congress, Messolonghi, 20-23 January 2000, 169-172. (In Greek).

Economou AN, Barbieri R, Daoulas CH, Psarras T, Stoumboudi M, Bertahas I, Giakoumi S, Patsias A. 1999. Endangered freshwater fish of western Greece and the Peloponnese - measures for protection. Final Technical Report, National Centre for Marine Research, 341 p. (In Greek).
Economou AN, Giakoumi S, Vardakas L, Barbieri R, Stoumboudi M, Zogaris S. 2007. The freshwater ichthyofauna of Greece: An update based on a hydrographic basin survey. Mediterr Mar Sci 8: 91-168.

Economou AN, Zogaris S, Vardakas L, Koutsikos N, Chatzinikolaou Y, Kommatas D, Kapakos Y, Giakoumi S, Oikonomou E, Tachos V. 2016. Developing policy-relevant river fish monitoring in Greece: Insights from a nation-wide survey. Mediterr Mar Sci 17: 302-322.

Excoffier L, Lischer HEL. 2010. Arlequin suite ver 3.5: a new series of programs to perform population genetics analyses under Linux and Windows. Mol Ecol Resour 10: 564-567.

Freyhof J, Kärst H, Geiger M. 2014. Valencia robertae, a new killifish from southern Greece (Cyprinodontiformes: Valenciidae). Ichthyol Explor Freshw 24: 289-298.

Freyhof J, Lieckfeldt D, Bogutskaya NG, Pitrab C, Ludwig A. 2006. Phylogenetic position of the Dalmatian genus Phoxinellus and description of the newly proposed genus Delminichthys (Teleostei: Cyprinidae). Mol Phylogenet Evol 38: 416-425.

Geiger MF, Herder F, Monaghan MT, Almada V, Barbieri R, Bariche M, Berrebi P, Bohlen J, Casal-Lopez M, Delmastro GB, Denys GPJ, Dettai A, Doadrio I, Kalogianni E, Kärst H, Kottelat M, Kovačić M, Laporte M, Lorenzoni M, Marčić Z, Özuluğ M, Perdices A, Perea S, Persat H, Porcelotti S, Puzzi C, Robalo J, Šanda R, Scheneider M, Šlechtová V, Stoumboudi M, Walter S, Freyhof J. 2014. Spatial heterogeneity in the Mediterranean biodiversity hotspot affects barcoding accuracy of its freshwater fishes. Mol Ecol Resour 14: 1210-1221.

Hall T. 1999. BioEdit: A user-friendly biological sequence alignment editor and analysis program for Windows 95/98/NT. Nucleic Acids Symp Ser 41: 95-98.

Jombart T. 2008. adegenet: a R package for the multivariate analysis of genetic markers. Bioinformatics 24: 1403-1405.

Kalogianni E, Koutsikos N, Vardakas L, Giakoumi S, Chatzinikolaou Y, Oikonomou A. 2019. Impacts of the alien mosquitofish on the abundance and condition of two Mediterranean native fish. Mediterr Mar Sci 20: 727-735.

Ketmaier V, Bianco PG, Cobolli M, Krivokapić M, Coniglia R, De Matthaeis E. 2004. Molecular phylogeny of two lineages of Leuciscinae cyprinids (Telestes and Scardinius) from the periMediterranean area based on cytochrome b data. Mol Phylogenet Evol 32: 1061-1071.

Ketmaier V, Bianco PG, Durand JD. 2008. Molecular systematics, phylogeny and biogeography of roaches (Rutilus, Teleostei, Cyprinidae). Mol Phylogenet Evol 49: 362-367.

Kokkoris IP, Bekri ES, Skuras D, Vlami V, Zogaris S, Maroulis G, Dimopoulos D, Dimopoulos P. 2019. Integrating MAES implementation into protected area management under climate change: A fine-scale application in Greece. Sci Total Environ 695: 133530.

Kottelat M, Barbieri R. 2004. Pseudophoxinus laconicus, a new species of minnow from Peloponnese, Greece, with comments on the West Balkan Pseudophoxinus species (Teleostei: Cyprinidae). Ichthyol Explor Freshw 15: 147-160.

Kottelat M, Freyhof J. 2007. Handbook of European freshwater fishes. Kottelat, Cornol and Freyhof, Berlin, 646 p.

Koutsikos N, Zogaris S, Vardakas L, Tachos V, Kalogianni E, Šanda R, Chatzinikolaou Y, Giakoumi S, Economidis PS, Economou AN. 2012. Recent contributions to the distribution of the freshwater ichthyofauna in Greece. Mediterr Mar Sci 13: 268-277.

Koutsikos N, Zogaris S, Vardakas L, Kalantzi OI, Dimitriou E, Economou AN. 2019. Tracking non-indigenous fishes in lotic ecosystems: Invasive patterns at different spatial scales in Greece. Sci Total Environ 659: 384-400. 
Kumar S, Stecher G, Tamura K. 2016. MEGA7: molecular evolutionary genetics analysis version 7.0 for bigger datasets. Mol Biol Evol 33: 1870-1874.

Machordom A, Doadrio I. 2001. Evidence of a Cenozoic Betic-Kabilian connection based on freshwater fish phylogeography (Luciobarbus, Cyprinidae). Mol Phylogenet Evol 18: $252-263$

Oikonomou A, Leprieur F, Leonardos ID. 2014. Biogeography of freshwater fishes of the Balkan Peninsula. Hydrobiologia 738: 205-220.

Pascual M, Rives B, Schunter C, Macpherson E. 2017. Impact of life history traits on gene flow: a multispecies systematic review across oceanographic barriers in the Mediterranean Sea. PLOS ONE 12: e0176419.

Perea S, Bohme M, Zupančič P, Freyhof J, Šanda R, Özuluğ M, Abdoli A, Doadrio I. 2010. Phylogenetic relationships and biogeographical patterns in Circum-Mediterranean subfamily Leuciscinae (Teleostei, Cyprinidae) inferred from both mitochondrial and nuclear data. BMC Evol Biol 10: 1-27.

Perea S, Vukić J, Šanda R, Doadrio I. 2016. Ancient mitochondrial capture as factor promoting mitonuclear discordance in freshwater fishes: A case study in the genus Squalius (Actinopterygii, Cyprinidae) in Greece. PloS ONE 11: e0166292.

Perissoratis C, Conispoliatis N. 2003. The impacts of sea-level changes during latest Pleistocene and Holocene times on the morphology of the Ionian and Aegean seas (SE Alpine Europe). Mar Geol 196: 145-156.

Rambaut A, Drummond AJ, Xie D, Baele G, Suchard MA. 2018. Posterior summarization in Bayesian phylogenetics using Tracer 1.7. Syst Biol 67: 901-904.

Ronquist F, Teslenko M, van der Mark P, Ayres DL, Darling A, Höhna S, Larget B, Liu L, Suchard MA, Huelsenbeck JP. 2012. MrBayes 3.2: efficient Bayesian phylogenetic inference and model choice across a large model space. Syst Biol 61: 539-542.

Rozas J, Ferrer-Mata A, Sánchez-DelBarrio JC, Guirao-Rico S, Librado P, Ramos-Onsins SE, Sánchez-Gracia A. 2017. DnaSP 6: DNA sequence polymorphism analysis of large datasets. Mol Biol Evol 34: 3299-3302.

Šanda R, Vukić J, Choleva L, Kř́žek J, Šedivá A, Shumka S, Wilson IF. 2008. Distribution of loach fishes (Cobitidae, Nemacheilidae) in Albania, with genetic analysis of populations of Cobitis ohridana. Folia Zool 57: 42-50.

Santos AM, Cabezas MP, Tavares AI, Xavier R, Branco M, 2016. tcsBU: a tool to extend TCS network layout and visualization. Bioinformatics 32: 627-628.

Schönhuth S, Vukić J, Šanda R, Yang L, Mayden RL. 2018. Phylogenetic relationships and classification of the Holarctic family Leuciscidae (Cypriniformes: Cyprinoidei). Mol Phylogenet Evol 127: 781-799.
Templeton AR, Crandall KA, Sing CF. 1992. A cladistic analysis of phenotypic associations with haplotypes inferred from restriction endonuclease mapping and DNA sequence data. III. Cladogram estimation. Genetics 132: 619-633.

Towner P. 1991. Purification of DNA. In : Brown T. ed. Essential molecular biology, a practical approach, Oxford University Press, Oxford, 47-68.

Tsigenopoulos CS, Berrebi P. 2000. Molecular phylogeny of north Mediterranean freshwater barbs (genus Barbus: Cyprinidae) inferred from cytochrome $b$ sequences: biogeographic and systematic implications. Mol Phylogenet Evol 14: 165-179.

Vanhove MPM, Kovačić M, Zogaris S. 2016. A distinct island population of threatened freshwater fish: To split or lump? Hydrobiologia 777: 79-93.

Vavalidis T, Zogaris S, Economou AN, Kallimanis AS, Bobori DC. 2019. Changes in fish taxonomy affect freshwater biogeographical regionalisations: insights from Greece. Water 11: 1743.

Vogiatzi E, Kalogianni E, Zimmerman B, Giakoumi S, Barbieri R, Paschou P, Magoulas A, Tsaparis D, Poulakakis N, Tsigenopoulos CS. 2014. Reduced variation and strong genetic population structure in the freshwater killifish Valencia letourneuxi (Valenciidae) based on nuclear and mitochondrial markers. Biol J Linn Soc Lond 111: 334-349.

Vukić J, Kovačić M, Zogaris S, Šanda R. 2016. Rediscovery of Knipowitschia goerneri and its molecular relationships with other European northern Mediterranean Knipowitschia species (Teleostei: Gobiidae). Ichthyol Explor Freshw 26: 363-372.

Vukić J, Ulqini D, Šanda R. 2017. Occurrence of Knipowitschia goerneri Ahnelt, 1991 (Gobiidae) in southern Albania confirmed with molecular tools. J Appl Ichthyol 33: 284-290.

Yang L, Sado T, Hirt MV, Pasco-Viel E, Arunachalam M, Li J, Wang X, Freyhof J, Saitoh K, Simons AM, Miya M, He S, Mayden RL. 2015. Phylogeny and polyploidy: resolving the classification of cyprinine fishes (Teleostei: Cypriniformes). Mol Phylogenet Evol 85: $97-116$

Zardoya R, Doadrio I. 1999. Molecular evidence on the evolutionary and biogeographical patterns of European cyprinids. J Mol Evol 49: 227-237.

Zogaris S, Economou A, Dimopoulos P. 2009. Ecoregions in the Southern Balkans: should they be revised? J Environ Manage 43: 682-697.

Zogaris S, Economou AN. 2017. The biogeographic characteristics of the river basins of Greece. In Skoulidikis N, Dimitriou E, Karaouzas I, eds. The rivers of Greece, Springer, Berlin, Heidelberg, 53-95.

Zogaris S, Tachos V, Economou AN, Chatzinikolaou Y, Koutsikos N, Schmutz S. 2018. A model-based fish bioassessment index for Eastern Mediterranean rivers: Application in a biogeographically diverse area. Sci Total Environ 622: 676-689. 